\title{
The College Examination Reform under the Goal of Cultivating Innovative Talents
}

\author{
Chunfu Yang ${ }^{1,}$, , Dongliang Yang ${ }^{2, \mathrm{~b}}$, Weihong $\mathrm{Min}^{3, \mathrm{c}^{*}}$ and Yunping Zhang ${ }^{4, \mathrm{~d}}$
}

${ }^{1}$ College of Animal Science and Technology, Jilin Agricultural University, Changchun 130118, China

${ }^{2}$ College of Information and Technology, Jilin Agricultural University, Changchun 130118, China

${ }^{3}$ College of Food Science and Engineering, Jilin Agricultural University, Changchun 130118, China

${ }^{4}$ Financial Department, Jilin Agricultural University, Changchun 130118, China

*The corresponding author: Weihong Min, Professor, female, born in August, 1971, interested infood science

ayangchunfu197242@163.com, b610557217@qq.com, ㄷ5817713@qq.com, d798301739@qq.com

*The corresponding author

Keywords: Cultivation of innovative talents; College examination reform; Existing problems; Reform thinking; Realization of goal

\begin{abstract}
Innovative talents are required in the era of knowledge economy, while the cultivation of innovative talents depends on innovation education, which requires teachers of colleges to establish innovative educational philosophy, stand on the height of innovative education to examine the education and teaching activities, including examinations. The establishment of the training model and the security system for the training target of innovative talents are of special significance to the cultivation of innovative talents. This paper made an in-depth thinking on the problems existing in the reform of college examinations and put forward the feasible examination reform measures.
\end{abstract}

\section{Introduction}

The world has entered the era of knowledge economy, knowledge economy is an innovative economy, and innovation is its soul, talent is its key, therein, talent must be innovative one. While the cultivation of innovative talents must rely on education, which requires college educators must establish an innovative educational concept as soon as possible to enhance the awareness of innovation education, improve students' innovative ability, to create an environment which is conducive to the growth of innovative talents, cultivating the innovative talents not only holding knowledge and skills, but also innovative spirit.

\section{The Existing Problems in Current College Examination}

The exam is the baton of teaching and learning. Scientific and rational examination not only can work for teaching in evaluation, feedback and promotion, but also can mobilize the enthusiasm, initiative and creativity of students to cultivate students' innovative consciousness, innovation spirit and innovation ability, so as to make the students to adapt to the needs of the the times development.

Lack the Awareness of Innovation and Reform; Innovative Educational Ideas are not Enough. At present, the college reform has been carried out continuously, the examination as an important part of teaching activities, of course, is no exception, but looking back the examination 
reform, more works are staying in some normalization, standardization and institutionalization, do not improve the level of innovative education, do not consider whether the reform of the examination will help students to cultivate innovative thinking, stimulate students' awareness of innovation and promote the development of students' ability to innovate, so that the training target of innovative talent can't be completed.[1]

Examination form and Test Method are Single. The current form of college examination is relatively stiff, rigid model, narrow goals. The closed form are more than open mode, subjective questions are more than subjective questions, written test are more than oral test, the theoretical questions are more than practical problems, unified examination are more than multiple classification test, the final examination of a test to get conclusion are more than the formation of comprehensive evaluation through several assessments, the examinations for all people are more than individualized examinations. [2] This kind of examination can't effectively stimulate the initiative and creativity of students to learn, on the contrary, the students gradually form a "standard answer" type of solidified thinking, which tied the cultivation of students' innovative consciousness.

Test Content is Rigid with Narrow Coverage. Innovation is the core of innovative talent. Currently, the purpose with utilitarian for part of the students to learn is much stronger, they often learn what will be tested, and even ask the teachers to give the key points, just to pass the examinations by rote memorization, not to understand and digest the content. The phenomenon of cheating in examinations appears again and again. This is related to the relatively narrow coverage of the examination, which is not conducive to the cultivation of students' creative thinking, further resulting in failure of the formation of innovation ability. [3]Colleges should proceed from the professional characteristics, student grade and curriculum type and so on, to adjust the examination content, appropriately increase the subjective questions, focusing on testing the ability of students to use knowledge to analyze and solve problems.

The Feedback Function of the Exam is Poor. The examination is a sign of the end of the course for many teachers and students. Few teachers have carefully analyzed the results of the exams, made evaluations, and gave feedback to the students. The students are only concerned about the test marks, but rarely sum up the content of learning, which is not conducive to consolidate the knowledge for students to promote the future development and mobilize the enthusiasm of students to learn, but also not conducive to teachers improve teaching methods, optimize teaching content and improve teaching effectiveness based on test results, making it difficult to achieve to supervise and evaluate the teaching quality by the examination results, so the examination function in the teaching process will be weakened.[4]

\section{Reflections on the Current Examination Situation}

At present, many defects in college examinations have seriously affected the cultivation of innovative talents, restricting the development of colleges, therefore the reform of examinations is imperative. In view of the current situation, we should actively explore the new direction of examination reform to meet the goal of cultivating innovative talents with both solid theoretical basis and innovative consciousness and innovation ability.

Change the Form of Examination, Promote Personal Development. The college examination has multiple functions such as diagnosis, motivation, selection and testing, etc. The importance of those in education and teaching can't be replaced. At present, there are certain contingencies and irrationality in the traditional examination of "one time determines result", which can not effectively reflect the students' learning process, hinders the improvement of college education and the comprehensive ability of students, ignore the student-centered teaching idea.[5] The proposition of 
college examinations should treat the realization of the goal of cultivating innovative talents as the starting point and ultimate destination, and should pay attention to the students' innovative thinking and innovation ability.

Enrich the Examination Content, Improve Learning Interest. In order to adapt to the rapid development of society, we must establish the concept of lifelong learning, but for lifelong learning, we must guide students to have a strong interest in professional knowledge. Interest is the best teacher, so how to improve the students' Learning interest has become a major problem to be solved urgently. [6]The examination with rich content and diverse forms, can reflect the comprehensive ability, is an important means to improve the interest of learning, such that currently hot issues can be properly reflected in the examination papers, which do not ask students to solve these problems, only to hope that they can express themselves, in order to promote students to learn more about extracurricular knowledge, to enhance the ability to collect and deal with information, and thus achieve the purpose of cultivating innovative ability.

Strengthen the Examination Management, Promote Communication between two Sides. The examination management is the protection and booster of the examination reform. It is a systematic project involving in many personnel, business affairs and different departments. It is not only a simple examination management, while the examination organization, supervision and student achievement evaluation are a major education project, the focus of the examination management should be placed on argument of the examination papers before test and test papers analysis and summary after test.[7] We should improve the whole, educated and scientific examination management. Through the examination, teachers can find the teaching problems, sum up experience, improve teaching, while students can check mistakes and deficiency through the examination, and continue to learn.

\section{Boost the Reform of College Examination, Achieve the Goal of Cultivating Innovative Talents}

The reform of college examinations should establish the concept that examinations are aiming at cultivating innovative talents, adhere to the unity of process evaluation and the end evaluation, the combination of comprehensive training and personality development, to establish a sound and times organizational system and protection mechanism. For that, the following reform measures are proposed:

Change the Education Concept, Reform Evaluation Criteria. Under the guidance of the goal of cultivating innovative talents, higher education should change from "imparting knowledge" to "teaching method", "granting people with fish is not better than teach them the skills". This requires that we must establish a modern concept of education, talent and examination, change the kind of obstacles to the spirit of innovation and creative development of the educational concept and education model, abandon education system that the test scores are treated as the unique measure to inspect education fruit. [8]Assessing and selecting talents by treating innovative education as the core assessment, supervising the common progress for both sides in the teaching process.

Implement the Teaching of Cultivating Ability, Complete the Change From "Test Knowledge" to "Test Ability". The design of teaching objectives should combine "knowledge" and "ability" simultaneously, pays attention to both theory and practice. In the process of imparting knowledge, teaching should ask students to learn to use the knowledge to solve practical problems, guiding students to participate in innovative activities, to achieve to use what has been learnt and cultivate the ability of students to combine theory with practice. We can use a variety of assessment methods to test the ability of students from different aspects.[9]

Establish a Reasonable Assessment System, Change From Teaching Based on the Subject to 
Testing Based on the Subject. It is obviously incompatible to conclude the good or bad based on examination result in the era of knowledge explosion, objectively giving rise to the despite of cultivating innovative ability, which neglect and suppress students' innovative consciousness, innovation spirit and innovation ability. In order to adapt to the development of the times, we must get rid of the shackles of traditional thinking, put forward different assessment methods for different students, In order to achieve the maximum assessment benefits.

Improve the Scientific and Rational Examination Reform Mechanism. College examination reform is a systematic project, in need of multi-party participation, unified coordination, full monitoring and the whole implementation. Establish the examination reform group where president is the leader, To strengthen exam supervision regulation, perfect the exam form and establish the exam supervision system for practice assessment. Strengthen the quality assessment, not only to make the quantitate and qualitative analysis on the quality of the examination, but also to analyze the ability of the students to understand and use knowledge based on the answers. [10]We should stablish and improve the examination mechanism, explore the form of examination, innovative test content to meet the needs of form development.

\section{Summary}

In short, in order to adapt to the development of society, to achieve the goal of cultivating innovative talents, the college examination reform is imminent, has a long way to go, while the mission is glorious and opportunity is few, we must focus on the core of cultivating innovative talents, establish the examination mode in demand, so that the examination can really be able to comprehensively test the knowledge, ability and quality of students, and gradually realize the goals of cultivating innovation ability and innovative spirit of college students.

\section{References}

[1] Y.L.Duan: Study of China's college entrance examination system reform [M] Journal of China Youth University for Politics Sciences, 2014 (5): 119-123. (In Chinese)

[2] Zh.W.Cheng: Innovative talents training and university examination reform[J] Liaoning Education Research, 2015 (5): 25-26. (In Chinese)

[3] Q.Chen: Discussion on university examination reform from the perspective of quality education [J]. Higher Education Exploration, 2015 (2): 77-78. (In Chinese)

[4] W.B.Cai: Reform of the examination system to cultivate innovative talents[J]. Educational Development Research, 2012 (12): 47-49. (In Chinese)

[5] F.Li, K.Xu: Reform examinations, guiding the competition to a higher level[J]. Higher Engineering Education Research, 2011 (3): 65-67. (In Chinese)

[6] Z.J,Shao, W.M.Pei: Education[M]. East China Normal University Press, 1996.

[7] W.P.Tan: Discussion on the university's educational innovation and innovation education[J]. Huaihua Teachers College, 2012, Supplementary Issue. (In Chinese)

[8] J.H.Liu:Reflections on the reform of college examinations[J]. China Higher Education Research, 2013 (5): 23-25. (In Chinese)

[9] B.Y.Guo: Study on the Disadvantages of the separation of education and examination [J]. Journal of Nantong Teachers College, 2012 (2): 18-20. (In Chinese) 
[10]K.B.Chen: How the examination system to face the new century[N]. Guangming Daily, 2014.1.25. (In Chinese) 